\title{
ASSESSMENT OF UNCERTAINTY WHILE SELECTING THE OPERATIONAL STRATEGY BY THE INDUSTRIAL ENTERPRISES IN ROMANIA
}

\author{
Vasilica RUSU, PhD Student, \\ Free International University Of Moldova
}

DOI: https://doi.org/10.36004/nier.es.2021.1-07

JEL Classification: D18, D81, L60, L61, L65, L66, L74

UDC: 005.53(498)

\section{ABSTRACT}

In conditions of uncertainty, an enterprise should have a rational basis for making decisions, which would enable the comparison of different alternatives and the choice of the most suitable action for achieving its objectives. Some researchers consider that uncertainty is generated either by insufficient knowledge about the nature of phenomena and processes or by the lack of information about these phenomena and processes. The author considers that these interpretations need to be completed by clarifying the motives which cause uncertainty. The following types of environment can be distinguished which could be considered as sources of uncertainty: socio-economic; scientific and technical; political and juridical; the sales partners' environment; the environment of the seller; the competitors' environment; the consumers' environment; the investments environment. The aim of the present paper is to determine the degree of influence (markedness) of each type of uncertainty upon the decisions made while selecting the operational strategy by the industrial enterprise. The research has been carried out at 29 enterprises from different industrial fields from Romania: metallurgical industry, production of basic pharmaceuticals and pharmaceutical preparations, construction materials industry, food-processing industry, manufacture of chemical substances and products. The management teams of those companies have taken part in the survey. The research is based on the data processing and analysis obtained from 256 questionnaires. The survey carried out within the industrial enterprises has shown that the uncertainty from the consumption environment has the biggest impact upon the operational decisions of the companies. The uncertainty from the internal, political, juridical, scientific and technical environment is being analyzed to a lesser extent. The lowest domain of uncertainty is characteristic for the chemical industry and the highest for the industry of manufacture of basic pharmaceuticals and pharmaceutical preparations.

Key words: uncertainty, decision making, operational strategy, information, fuzzy variable

In condiții de incertitudine, o întreprindere trebuie să aibă o bază rațională pentru luarea deciziilor, care să permită compararea diferitor alternative și alegerea celei mai potrivite acțiuni pentru atingerea obiectivelor sale. Unii savanți consideră că incertitudinea este generată fie de cunoașterea insuficientă a naturii fenomenelor și proceselor, fie de lipsa de informații despre aceste fenomene și procese. Autorul consideră ca aceste interpretări au nevoie de completare, concretizând cauzele care generează incertitudinea. Se disting următoarele tipuri de medii, care pot fi considerate surse de incertitudine: socio-economic; științific și tehnic; politic și juridic; mediul partenerilor de vânzări; mediul vânzătorului; mediul concurenților; mediul consumatorilor; mediului investițional. Scopul acestei lucrări este de a determina gradul de influență (evidență) al fiecărui tip de incertitudine asupra deciziilor luate la selectarea strategiei operaționale de către întreprindere industrială. Cercetarea a fost realizată în 29 de întreprinderi din diferite ramuri industriale din România: industria metalurgică, fabricarea produselor farmaceutice de bază și a preparatelor farmaceutice, industria materialelor de construcție, industria alimentară, fabricarea substanțelor și a produselor chimice. În sondaj au participat echipe managerile ale acestor companii. Studiul se bazează pe procesarea și analiza datelor obținute din 256 de chestinare. Sondajul realizat în cadrul întreprinderilor industriale a arătat că cel mai mare impact asupra deciziilor operaționale ale companiilor îl are incertitudinea generată în mediul de consum. Într-o mai mică măsură, se analizează incertitudinea mediului intern, politic, juridic, științific și

\footnotetext{
${ }^{1}$ ID ORCID 0000-0002-6534-5638 $₫ e$ e-mail: officeaesms@yahoo.com
} 
tehnic. Cel mai mic domeniu de incertitudine este caracteristic industriei chimice și cel mai mare pentru industria de fabricarea produselor farmaceutice de bază și a preparatelor farmaceutice.

Cuvinte-cheie: incertitudine, luarea deciziilor, strategia operațională, informații, variabile fuzzy

В условиях неопределенности у предприятия должна быть рациональная основа для принятия решений, позволяющая сравнивать различные альтернативы и выбирать наиболее подходящие действия для достижения своих целей. Некоторые исследователи считают, что неопределенность порождается либо недостаточными знаниями о природе явлений и процессов, либо недостатком информации об этих явлениях и процессах. Автор считает, что эти интерпретации необходимо дополнить выяснением мотивов, вызывающих неопределенность. Можно выделить следующие типы окружающей среды, которые можно рассматривать как источники неопределенности: социально-экономическая; научнотехническая; политическая и юридическая среда, среда торговых партнеров; окружение продавца; окружение конкурентов; окружающая среда потребителей; инвестиционная среда. Целью данной статьи является определение степени влияния (выраженности) каждого типа неопределенности на решения, принимаемые при выборе производственной стратегии промышленным предприятием. Исследования проводились на 29 предприятиях из различных областей промышленности Румынии: металлургической промышленности, производство основных фармацевтических препаратов и фармацевтических препаратов, производство строительных материалов, пищевой промышленности, производство химических веществ и продуктов. В опросе приняли участие руководители этих компаний. Исследование основано на обработке и анализе данных 256 анкет. Опрос, проведенный на промышленных предприятиях, показал, что наибольшее влияние на операционные решения компаний оказывает неопределенность со стороны среды потребления. Неопределенность внутренней, политической, юридической, научно-технической среды анализируется в меньшей степени. Самая низкая область неопределенности характерна для химической промышленности, а самая высокая - для отрасли производства основных фармацевтических препаратов и фармацевтических препаратов.

Ключевые слова: неопределенность, принятие решений, операционная стратегия, информация, нечеткая переменная

\section{INTRODUCTION}

The changes that are taking place in the domestic and international environment related to the orientation of economy towards modernization and developing innovations, increase of uncertainty for the market processes, modification of the business relations and interpenetration of economies, generate different problems in the management of operation activities of the industrial enterprises. Thus, the industrial enterprises represent complex diffused systems, whose efficiency relies essentially on the quality of management of the operational system. One of the most important conditions for the prosperity of the Romanian economy constitutes the high efficiency of the production processes which involves the rational utilization of resources, improvement of operational processes, strategic planning of the operational activity taking into account the factors of uncertainty, improvement of quality and product competitiveness. The technological and productive development is often overshadowed by the new scientific tendencies, but namely the operational activity constitutes the basis without which it is impossible to rationalize and build an efficient economic structure.

Modifications of the socio-economic life related to modernization and technocracy, which have started in the second half of the XX century, have undoubtedly had an impact upon the production relations. Managerial decisions are being taken in every economic system, including the industrial one. The new circumstances for making decisions which constantly appear, lead to the emergence of several alternatives for development and significantly complicate the development of the operational strategy.

The uncertainty and risk could be regarded as interdisciplinary phenomena. At the same time, the uncertainty and risk, as a rule, are taken into consideration in the context of analysis of 
the decision making processes. In conditions of uncertainty and risk, an enterprise should have a rational basis for making decisions, which would enable comparing different alternatives and choosing the most suitable action in order to achieve its objectives.

The impossibility of performing an accurate forecast of events characterizes most of the strategic problems of the enterprise, especially, according to some authors, the uncertainty in the modern world becomes increasingly differentiated and its range becomes broader.

\section{THE DEGREE OF THE TOPIC'S SCIENTIFIC RESEARCH IN SCIENTIFIC LITERATURE}

Reflections regarding uncertainty persist among the economists from different eras. Thus, J.M. Keynes operates with the term „uncertainty”, describing the probability of how much a family would spend or save, or what interest would some investments bring in fixed assets (Keynes et al., 2009). He distinguishes in the uncertain knowledge what is veridical known and what is possible. It is important the fact that J.M. Keynes highlighted the subjectivity of planning the probability of emergence for some events in the future, based on the patterns discovered in the past. In other words, planning the degree of uncertainty is difficult.

According to the explanatory dictionary of the Romanian language, the concept of "uncertainty" means a doubtful, unsure, unexplored thing [3]. According to linguists, the interest towards the phenomenon of uncertainty is due to the fact that this is one of the basic principles of human logic. The uncertainty in philosophical papers is regarded as a subjective and objective characteristic of a human being. From the subjective point of view, the uncertainty is an attribute not of a situation, but of a subject who takes decisions. However, from a more general perspective, the uncertainty is independent having an objective character in relation to the business, economy and society altogether.

In the dictionary of economic terms, uncertainty is treated as a lack of information, a total or partial absence of information, ignorance. In general, the economic interpretation of uncertainty does not contradict the linguistic and social language. At the same time, it would be necessary to have a thorough analysis of opinions of this phenomenon in business.

George Cristian Maior pointed out that uncertainty in the socio-economic field is a social form of movement of matter, which includes at the genetic level, forms of organization which are characterized by a high degree of variability and uncertainty. As we can see, he suggested that the tendency of growth for the instability is conditioned by the role of the subjective factor - the presence of crises or a transition period. Nevertheless, it would be more correct to identify an objective representation of uncertainty.

For instance, Jonathan Fields notices the fact that the degree of development is an inherent phenomenon of the internal movement in order to overcome the conflict (uncertainty) at a new order (Fields, 2012, p.21). Thus, it is obvious that the uncertainty is an objective attribute existent in any functional socio-economic system. Regarding the uncertainty in the socio-economic environment, we could add the opinion of the researcher Zamfir Cătălin, who mentions that the peculiar nature of the uncertainty of the social processes is determined by the subjective factor to the causal multilateral and multifactorial relations, the main statistics, the uncertainty of many social laws and regularities and consequently, in the social field the distinction between certainty and uncertainty is more conditioned and more relative than in the study of the natural phenomena (Zamfir, 2005, p.32). Moreover, in the analyzed definitions, the informational aspect prevails for the preconditions of uncertainty. This fact is confirmed by the interpretation of Ms. Doltu Theodora, for whom the uncertainty represents a situation in which the information about the probable future events are completely or partially absent, a situation which cannot be evaluated (Doltu, 2006, p.15).

As mentioned above, the phenomenon of uncertainty has been extensively studied in the economic theory and represents a separate orientation for research. Uncertainty is an important factor in the economic relations, which dictates the need to use different methods of prognosis and reduction of risk degree. Risks systematization enables developing the necessary management tools. Many of the classifications are excessively detailed, in our opinion, while it is extremely important to take into consideration only those risks which lead to the loss of the planned 
revenues. It must be taken into account that the uncertainty increases exponentially, in proportion with the elimination of the assumed time event. Consequently, the selection of an operational strategy related to a lengthy period of time requires a more thorough examination of the uncertainty factor.

Under the influence of the dynamic transformations which have taken place in the post-industrial economy, the uncertainty of the external environment has also modified, while the independent and discreet changes which are not interconnected began to transform into systemic ones. Thus, in a continuous flow some economic constraints occur, respectively the reduction of costs, optimization of consumption, increase of the degree of complexity of products, new technologies, globalization, communication, increase of the volume of sales, opening of new emerging markets, absence of specialized work force, which have contributed so that the industrial environment would react and search for solutions in order to solve the above mentioned problems. Every new transformation leads to the change of the remaining components of the economic relations. As Khana R.B. remarked, the average duration of the life cycle of goods has decreased in comparison with the middle of the $20^{\text {th }}$ century, from three to four decades down to three to five years.

\section{SOURCES FOR THE USED DATA AND METHODS}

The following methods were applied in our research: the analytical method, comparison, deduction, induction; experimental methods: questionnaires, discussion, observation, quantitative and qualitative interpretation of experimental results.

The research was carried out in Romania, Bucharest region and Constanta county in the December 2018 - April 2019 period. 29 manufacturing enterprises have been researched within the following industries:

- Metallurgical industry: LAROMET SA, GRANTMETAL SA, FINE METAL SRL, STEEL INTERNATIONAL CENTER SRL, DOOSAN IMGB SA;

- Production of basic pharmaceuticals and pharmaceutical preparations: SC HOFIGAL EXPORTIMPORT SA ANTIBIOTICE SA TIS FARMACEUTIC SA, LABORMED ALVOGEN SA, CRIDA PHARM SRL, MAGISTRA C\&C SRL;

- Construction materials industry: WIENERBERGER SISTEME DE CĂRĂMIZI SRL, DALCOR SRL, LAFARGE CIMENT (ROMÂNIA) SA, OMCO SRL, C \& B GLASS SOLUTIONS SRL, SOCERAM SA, FERCO CAPITAL SA;

- Food-processing industry: STAR FOODS E.M. SRL, PROD COM MARCO T.16 SRL, INTERSNACK ROMANIA SRL, ELIDOR SRL, PLAFAR SA, TIP TOP FOOD INDUSTRY SRL;

- Manufacture of chemical substances and products: CHIMTITAN SRL, INTERSTAR CHIM SA, A \& G PRODEXIM SRL,VOLA COLOR PROD SRL, SANTO RAPHAEL SRL.

5-10 questionnaires had been distributed within each enterprise for their managerial team. 256 questionnaires had been processed overall. Every manager had evaluated through the questionnaire the degree of influence of uncertainty, which appears in one of the following environments: social-economic, scientific-technical, political-juridical, distribution partners, the suppliers' environment, the medium of competitors, consumers, internal and investment environment. The evaluation was carried out on a scale of 10 points: 1 point - a weak influence, 10 points - a strong influence.

\section{THE RESULTS OF OUR RESEARCH AND DISCUSSION}

In order to identify the main sources of uncertainty through the perspective of the business environment, we have analyzed the existent opinions regarding their nature. Some researchers such as (McConnell, 2016), "From its origins in Newtonian physics, potential theory has developed into a major field of mathematical research. This book provides a comprehensive treatment of classical potential theory: it covers harmonic and subharmonic functions, maximum principles, polynomial expansions, Green functions, potentials and capacity, the Dirichlet problem and boundary integral representations. The first six chapters deal concretely with the basic theory, and include exercises. The final three chapters are more advanced and treat topological ideas specifically created for potential theory, such as the fine topology, the 
Martin boundary and minimal thinness. The presentation is largely self-contained and is accessible to graduate students, the only prerequisites being a reasonable grounding in analysis and several variables calculus, and a first course in measure theory. The book will prove an essential reference to all those with

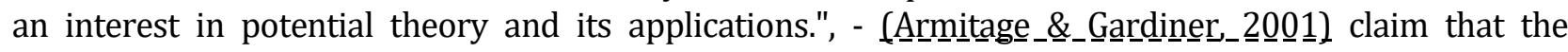
uncertainty is generated either by the insufficient knowledge of the nature of phenomena and processes, or by the lack of information about these phenomena and processes. The author believes that these interpretations need to be completed, by clarifying the causes which generate uncertainty. In this context, the following types of environment can be distinguished, that could be considered sources of uncertainty:

- socio-economic environment, in which the macro-factors of uncertainty are likely to manifest, dictating a certain development of the markets and regions, in which the enterprise is carrying out economic activities (macroeconomic indicators dynamic, legislative amendments, political transformations);

- scientific and technical environment, revolutionary modifications which could lead to significant operational changes at the level of the enterprise;

- political and juridical environment, which is the source of the legislative acts that dictate the political conditions for business management and regulations in force;

- environment of the distribution partners, conditioned by the activities of partners of the enterprise, the economic activity, financial situation, all of which have a direct impact upon their capacity to meet their obligations.

- environment of the supply partners, which reflects the future moves of the suppliers, including those that are expressed in the modification of the supply terms;

- competitive environment, including the change of the competitors' degree of influence and behavior

- consumers' environment, on which relies the state, dimension, dynamic and stability of the demand;

- internal environment, which could be considered as a source of conflict that leads to disturbances; the team work which increases the efficiency of the system in which the human and technical factors are closely intertwined and could produce some unforeseen results expressed in the level of product quality. The degree of awareness regarding the state of all these environments relies on the organization of work within the enterprise.

A study of the industrial enterprises management was carried out within the framework of this research. This study was undertaken in order to determine the degree of influence (markedness) of each type of uncertainty upon the decisions made when an operational strategy is being selected. The general evaluation through the calculation of the average of the indicated points by the representatives of all the interviewed enterprises is presented in Figure 1.

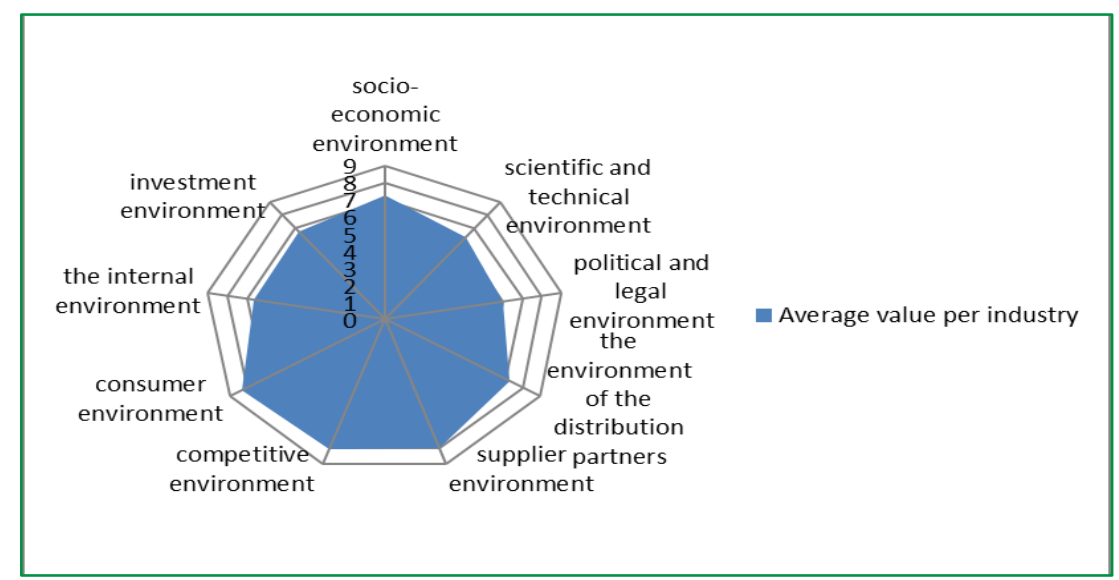

Figure 1. Evaluation of the influence of different types of uncertainty upon the decision making process regarding the operational strategy for the industry

Source: Elaborated by the author

As it can be noticed, the biggest impact upon the operational decisions of an enterprise are caused by the uncertainties generated by the consumers' environment. 
At the same time, the uncertainty of the internal, political, juridical, scientific and technical environment are being analyzed to a lesser extent. In other words, it could be asserted that the entrepreneurs' trust in the stability the organizational staff, managerial, technological stability and other components of their enterprise's activities, could conceal certain "traps" of inefficiency.

The generalized evaluation of the impact of different types of uncertainties upon the decision making process regarding the operational strategy for the metallurgical industry is shown in Figure 2.

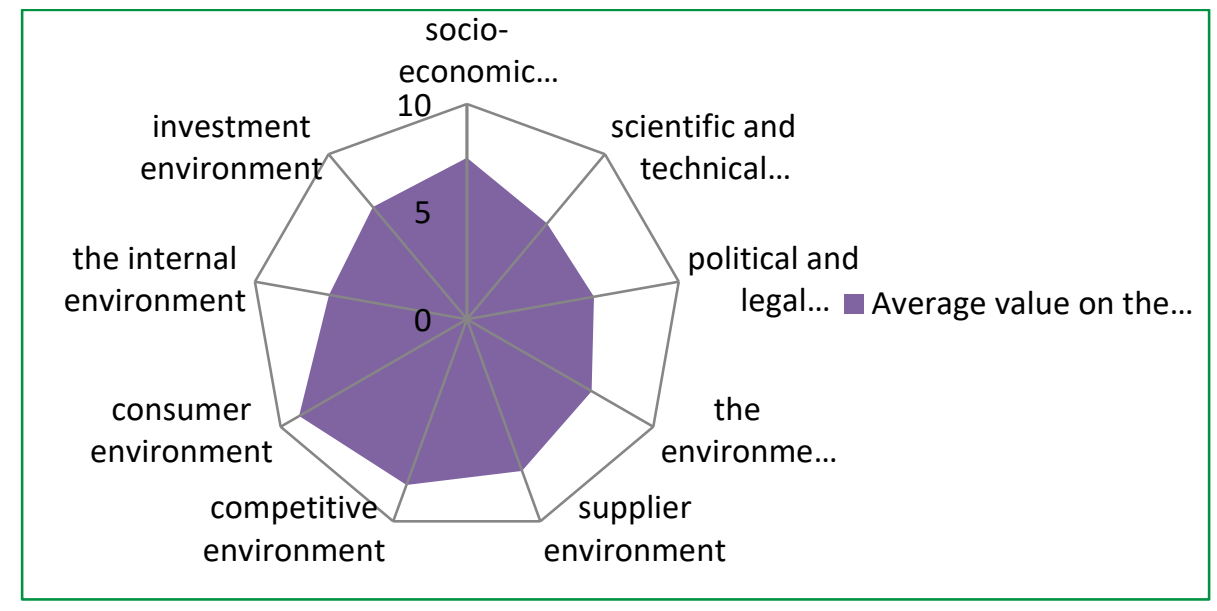

Figure 2. The impact of different types of uncertainties upon the decision making process regarding the operational strategy for the metallurgical industry

Source: Elaborated by the author

The data from Figure 2 show us that for the metallurgical industry the biggest impact upon the decision making process related to the operational strategy belongs to the consumers and competitors' environment.

The generalized evaluation of the influence of different types of uncertainties upon the decision making process related to the operational strategy for the production of basic pharmaceuticals and pharmaceutical preparations is shown in Figure 3. Here we can notice that the environment of consumers, competitional and the environment of the suppliers exercise a major influence upon these industries.

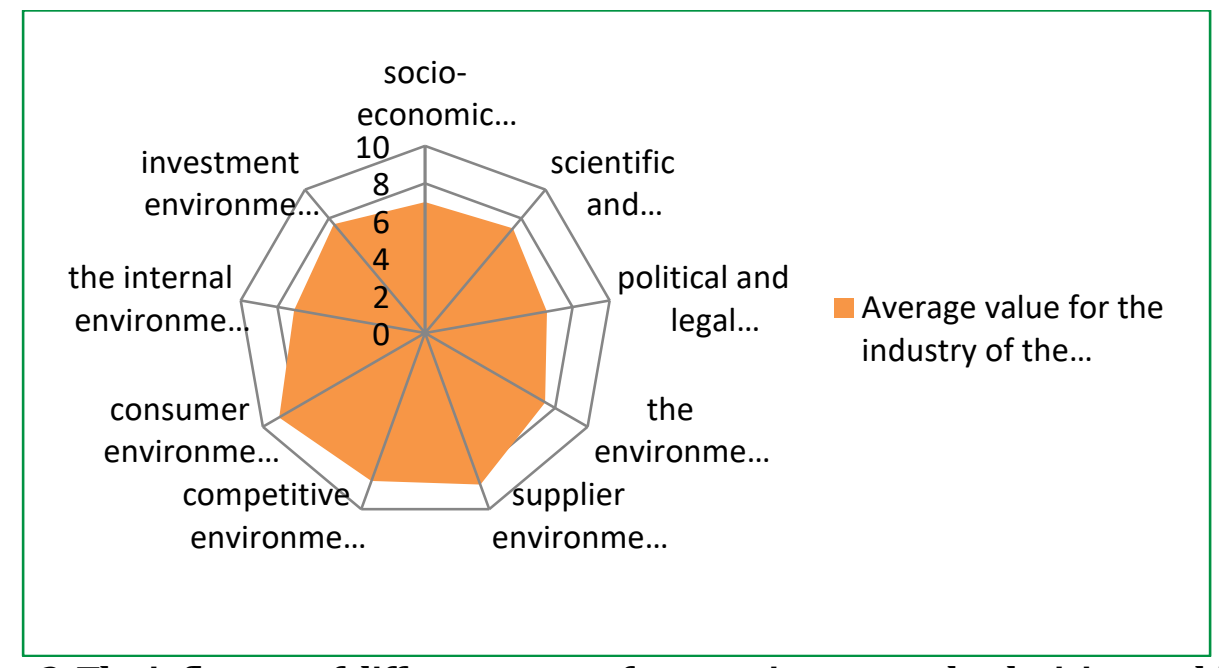

Figure 3. The influence of different types of uncertainty upon the decision making process related to the operational strategy for the industry of the production of basic pharmaceuticals and

Source: Elaborated by the author pharmaceutical preparations 
A general evaluation of the impact of different types of uncertainty upon the decision making process regarding the operational strategy for the construction materials industry is shown in Figure 4. The industry of construction materials is influenced in its operational activity mostly by the factors of the socio-economic environment, by competitors and suppliers.

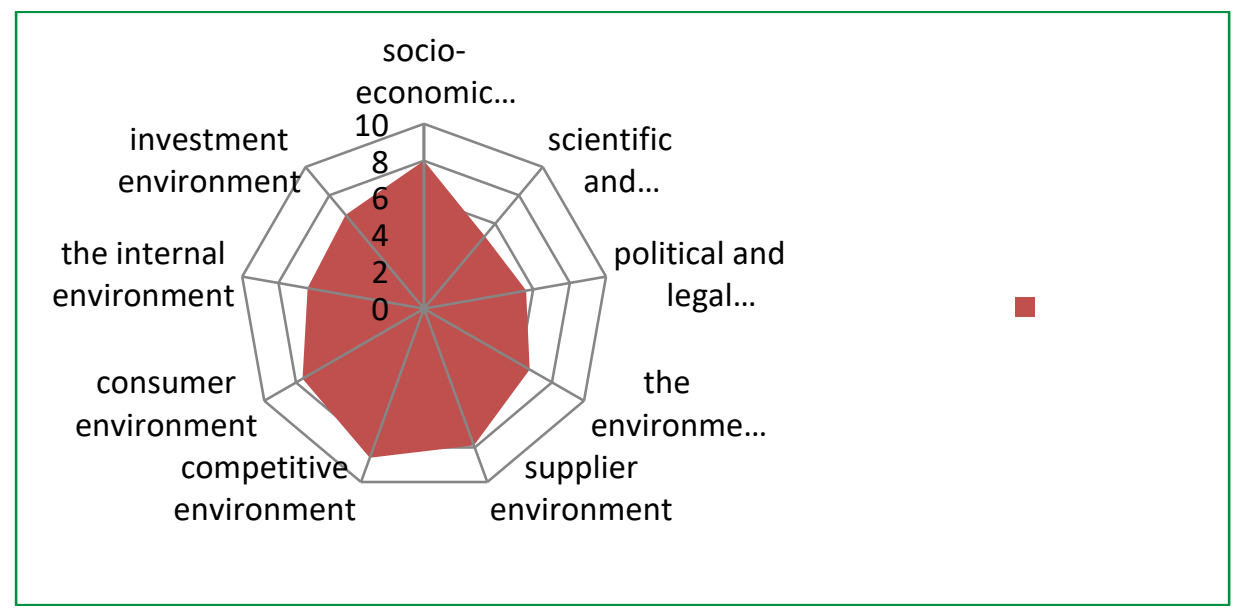

Figure 4. The impact of different types of uncertainty upon the decision making process regarding the operational strategy for the industry of construction materials Source: Elaborated by the author

The generalized evaluation of the influence of different types of uncertainty upon the decision making process regarding the operational strategy for the food-processing industry is presented in Figure 5.

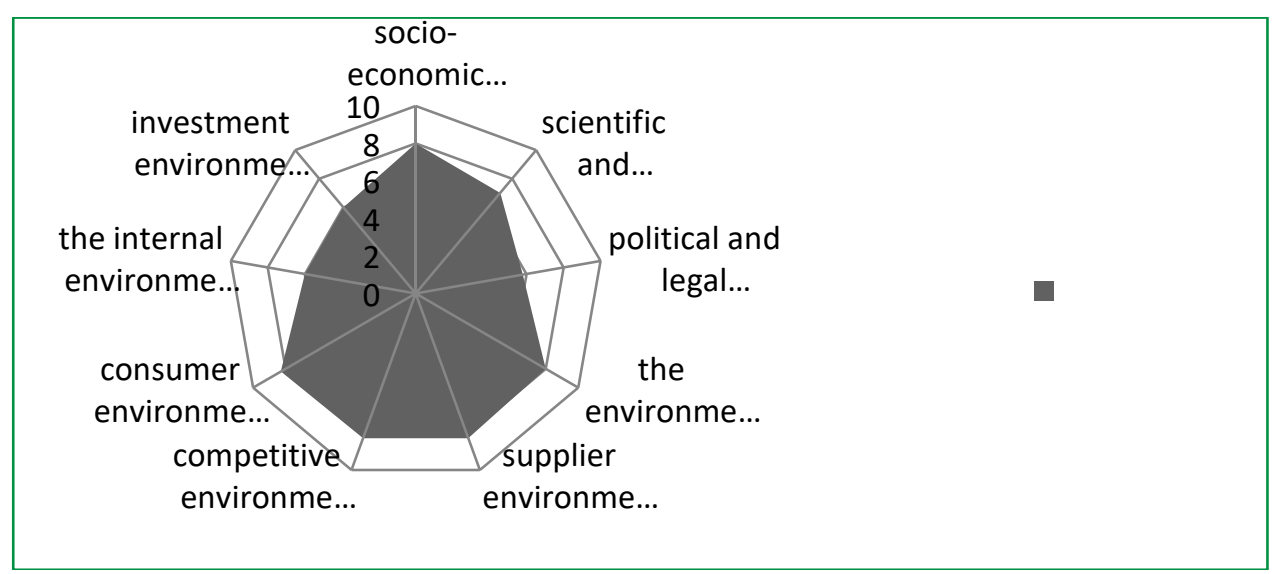

Source: Elaborated by the author

Figure 5. The influence of different types of uncertainty upon the decision making process regarding the operational strategy for the food-processing industry

We can notice in Figure 5 that the decision making process regarding the operational activity of the food-processing enterprises is influenced by the consumers' environment, environment of the competitors, environment of the supply partners and socio-economic environment.

A generalized evaluation of the impact of different types of uncertainty upon the decision making process regarding the operational strategy for the industry of chemical substances and products is provided in Figure 6, where we could readily notice that for this industry the internal environment, environment of consumers, competitors, environment of suppliers and the one of distribution partners matters the most. 


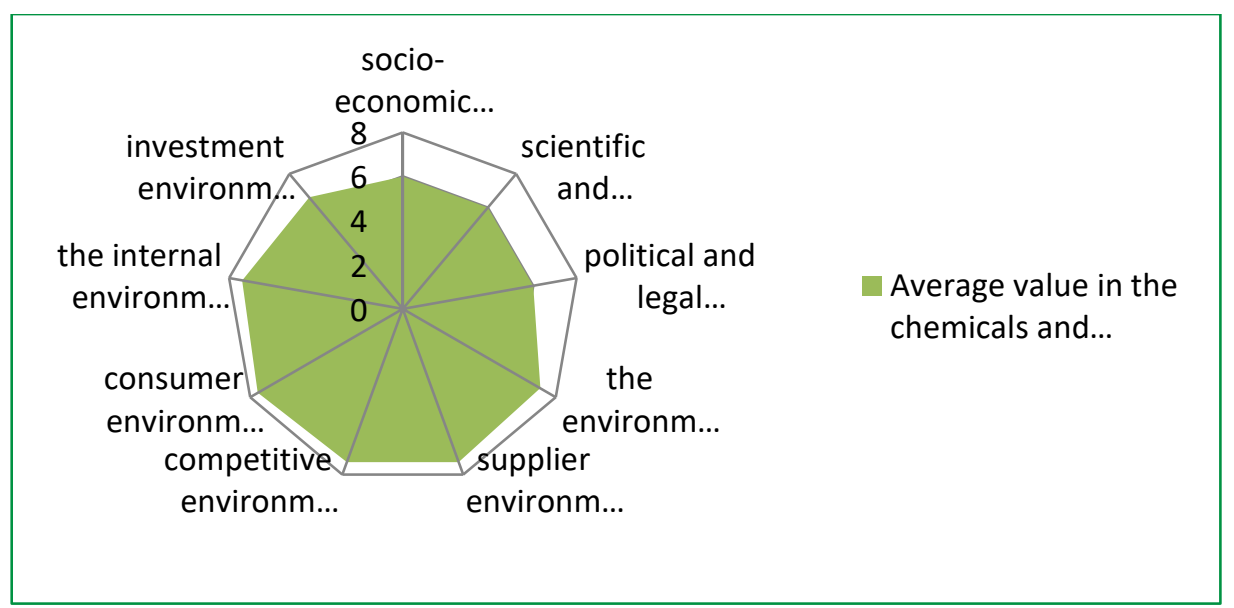

Figure 6. The impact of different types of uncertainty upon the decision making process regarding the operational strategy for the industry of chemical substances and products Source: Elaborated by the author

It can be noticed that the smaller the surface of the figure in the diagram is the less enterprises from the analyzed industry (Figures 1-6) feel the uncertainty in making the decisions regarding the operational strategy. It seems that the smallest field of uncertainty is characteristic for the industry of chemical substances and products and the largest - for the industry of the production of basic pharmaceuticals and pharmaceutical preparations.

Further on, we are going to proceed by introducing briefly the economic aspects of development for the pharmaceutical industry, in order to find the considerable sources of uncertainty, which occur in an environment of administrative decision making. Subsequently, we are going to proceed to the description of uncertainty measurement method.

As we know in Romania, the industry of pharmaceuticals is one of the most profitable, holding a special place in the Romanian economy. In the medical field there is a need of more flexibility as much regarding the medical programs, health ones, as more cooperation at the director plan carried out by the agents from tourism.

At present, the pharmaceutical industry from Romania is sufficiently developed to face the challenges [1]. In the 2000s, the majority of pharmaceutical factories have entered the circuit of multinationals, which have not shut them down, but on the contrary, competed in investing in technical refurbishment, development, export. However, due to the lack of a national drug strategy for the period of 2010-2014, Romania has lost the production of 40\% from the production volume of drugs, a national institute in the field was closed, a private producer was closed and not even a single portfolio investment was brought to Romania.

However, in 2015, the Government adopted the National Strategy for Competitiveness 2015-2020, where the pharmaceutical industry represents a strategic direction for Romania. Despite the fact that at present there are different fiscal barriers, problems of price calculation, regulation, economic diplomacy, legislative desynchronization, which continue to affect the interest for development of the industry, according to the statistical data in 2016 in Romania there were 158 officially registered manufacturers of drugs and pharmaceutical preparations and over 6700 wholesalers and retailers. At present, drugs worth about 350 million euro are being exported. Therefore, the development of this industry should be systemic and it should be designated as a strategic economic domain of national interest (Armitage \& Gardiner, 2001).

The pharmaceutical industry from Romania is a low-risk sector (as the economic theory suggests), playing a role in reducing the scale of the business cycle. This conclusion has been reached through dividing the economy of Romania in three risk categories (high risk, average risk and low risk), depending on sensitivity of the activity of an economic sector during a business cycle. On the other hand, the small contribution of pharmaceutical industry to the total added value does not enable this leverage to generate major positive results. By creating conditions for a strong development of the pharmaceutical industry from Romania would also support the shock-absorbers with counter-cyclical effect of the economy overall.

In modern economy, at the same time with the increase of the information flow, there is an objective need for continuous growth of employees' skills, an increase of the number of modernization projects, which would reduce the consumption of work force and materials, development of industrial marketing tools and increasing the operational efficiency. The pharmaceutical industry needs flexibility like no other industry, which would 
make possible a rapid reconstruction. Nowadays, $15 \%$ from the trade deficit of Romania is caused by the pharmaceutical industry, which imports annually drugs in an amount worth more than 8 billion lei, but manages to export an amount worth less than 1 billion. And all this under the conditions in which the Romanian pharmaceutical enterprises are paying duties and taxes to the Romanian state as much as are paying all the other providers of services and goods who are activating in the health domain all taken together [71]. One of the main opportunities for increasing the flexibility consists in a more complete utilization of modern computerized technology. A positive evolution consists in attracting portfolio investments in the pharmaceutical industry from Romania which would allow the concentration of financial resources to implement new developments taking into consideration market requirements in optimal terms.

Further on we will proceed to describe the model of uncertainty assessment. The main result of the evaluation is the value of damages that could occur within an enterprise in the case of exposure to diverse factors. At the same time, this interpretation, as we can perceive it, does not completely reflect the essence of the concept of "uncertainty". As it has been mentioned above, the uncertainty is associated with a lack of information, but the uncertain events could not only have a negative result, but a positive one, as well. Proceeding so, we are supposing that the probability of a positive result and a negative one could be different. There exist all the preconditions to divide the uncertainty into positive and negative. In order to attribute a situation in which the operational strategy is being developed to one or another variant of uncertainty, it is necessary to analyze all the possible consequences which could appear in the uncertainty environments and to study the possible results and the probability of their emergence. At the same time, as a result we understand in this case the degree of reaching the established objectives in the operational strategy.

Below we are going to present the stages of the evaluation methodology of uncertainty:

1. Finding out the situations of uncertainty in the environments of activity of the enterprise, which appear during the implementation of the operational strategy.

2. Defining a group of experts for the evaluation of consequences from the occurrence of each group of risk

3. Evaluation of every situation of uncertainty from the point of view of consequences and the probability of their occurrence. Assessing the risk degree of the operational strategy (the uncertainty of the environment for its implementation) in our opinion, could be achieved with the help of the expert system in the form of fuzzy variables,(Mora-Camino \& Nunes Cosenza, 2018, Hammer et al., 2016, p.87). This methodology takes into consideration the damages and benefits which could result from the action of one or another factor of uncertainty or risk. Every expert should present his opinion regarding the consequences of the impact of a certain type of risk upon the enterprise in the form of a fuzzy number and more specifically they should indicate:

1) lower limit of the interval $\left(\mathrm{m}_{\mathrm{i}}\right)$, in which the expected result of the risk (uncertainty) of the operational activity would be localized;

2) upper limit of the interval $\left(\mathrm{n}_{\mathrm{i}}\right)$, in which the expected result of the risk of the operational activity would be localized;

3) the most probable limit of the interval $\left(\mathrm{p}_{\mathrm{i}}\right)$, in which the expected result of the risk of the operational activity would be localized;

4) upper most probable limit of the interval $\left(\mathrm{q}_{\mathrm{i}}\right)$, in which the expected result of the risk of the operational activity would be localized;

5) the degree of trust in their evaluation $\left(\mathrm{h}_{\mathrm{i}}\right)$.

Moreover, every opinion of the experts could be represented as a fuzzy number $A ;=\left(\underline{m}_{i} ; \underline{n}_{i} ; \alpha_{i} ; \beta_{i} ; h_{i}\right)$ where $\alpha_{i}=p_{i}-\underline{m}_{i}, \beta_{i}=\underline{n}_{i}-q_{i}$; The total evaluation of the predictions made by the experts is determined according to the formula (Mora-Camino \& Nunes Cosenza, 2018, p.27):

$$
\begin{aligned}
& \left(\left(\sum \mathrm{m}_{\mathbf{i}}-\sum \alpha_{\mathbf{i}}+\alpha\right) ;\left(\sum \mathrm{n}_{\mathbf{i}}+\sum \beta_{\mathbf{i}}-\beta\right) ; \alpha ; \beta ; \boldsymbol{h}\right) \\
\mathrm{A}_{1}+\mathrm{A}_{2}+\mathrm{A}_{3}+\mathrm{A}_{4}+\mathrm{A}_{5}+\mathrm{A}_{6}+\mathrm{A}_{7}= & \left(\left(\sum \mathrm{m}_{\mathrm{i}}-\sum \alpha_{\mathrm{i}}+\alpha\right) ;\left(\sum \mathrm{n}_{\mathbf{i}}+\sum \beta_{\mathbf{i}}-\beta\right) ; \alpha ; \beta ; \boldsymbol{h}\right)_{, . .}
\end{aligned}
$$




$$
\begin{aligned}
\text { where } & \alpha=h * \sum \alpha_{\mathbf{i}} / \mathbf{h}_{\mathbf{i}}, \quad \boldsymbol{\beta}=\mathbf{h} * \sum \beta_{\mathbf{i}} / \mathbf{h}_{\mathbf{i}}, \mathbf{h}=\min \left\{\mathbf{h}_{\mathbf{i}}\right\} \\
\alpha=h * \sum \alpha_{\mathbf{i}} / \mathbf{h}_{\mathbf{i}}, \quad \boldsymbol{\beta}=\mathbf{h} * \sum \beta_{\mathbf{i}} / \mathbf{h}_{\mathbf{i}}, \mathbf{h}=\min \left\{\mathbf{h}_{\mathbf{i}}\right\} &
\end{aligned}
$$

The result of the evaluation can be found out by calculating the arithmetic mean of experts' judgement: $\sum^{A_{i}} / \mathbf{k} \sum^{A_{i}} / \mathbf{k}$

, where $\mathrm{k}$ is the number of experts who are participating in the survey.

4. The calculation of the mean value of the result (R) for all the types of risk (uncertainty) is possible through the formula:

$$
R=\sum_{j=1}^{t} h_{J}-R_{j}
$$

Where: $h_{j}$ - the degree of trust of the group of experts regarding the factor $j$ of uncertainty; $R_{j}$ - the result of the evaluation of the group of experts regarding the factor $j$ of uncertainty; $t$ - is the number of experts.

The result of the evaluation would enable determining the degree of effect / damages caused by the appearance of the risk (uncertainty), which could be a preliminary measure for determining the need for implementing an operational strategy.

The approval of this method is proposed to be implemented at the pharmaceutical enterprise SC HOFIGAL EXPORT-IMPORT S.A, because as the analysis has shown, managers from the respective industry feel a significant impact of uncertainty while making managerial decisions. For every of the environments above mentioned, the

\begin{tabular}{|c|c|c|c|}
\hline No. & Environment & Negative uncertainty factors & Positive uncertainty factors \\
\hline 1 & $\begin{array}{l}\text { Socio-economic } \\
\text { environment }\end{array}$ & 1.1. Increase in prices (inflation) & 1.2. Reduction of the transport charges \\
\hline 2 & $\begin{array}{l}\text { Scientific-technical } \\
\text { environment }\end{array}$ & $\begin{array}{l}\text { 2.1. Development of substitutable } \\
\text { products }\end{array}$ & $\begin{array}{l}\text { 2.2. Emergence of new energy saving } \\
\text { technology }\end{array}$ \\
\hline 3 & $\begin{array}{l}\text { Politico-juridical } \\
\text { environment }\end{array}$ & 3.1. Increase of fiscal pressure & $\begin{array}{l}\text { 3.2. Implementation of a new program } \\
\text { for drugs production }\end{array}$ \\
\hline 4 & $\begin{array}{l}\text { Environment of the } \\
\text { business partners }\end{array}$ & $\begin{array}{l}\text { 4.1. Infringing the rhythm (schedule) } \\
\text { of selling }\end{array}$ & 4.2. Reduction of intermediary margins \\
\hline 5 & $\begin{array}{l}\text { Environment of } \\
\text { suppliers }\end{array}$ & 5.1. Inopportune delivery & 5.2. Reduction of cost of stock \\
\hline 6 & $\begin{array}{l}\text { Environment of } \\
\text { competitors }\end{array}$ & $\begin{array}{l}\text { 6.1. Prices decrease and switching of a } \\
\text { part of customers to the competitors }\end{array}$ & $\begin{array}{l}\text { 6.2. Prices increase and customers } \\
\text { switch from competitors to the targeted } \\
\text { enterprise }\end{array}$ \\
\hline 7 & $\begin{array}{l}\text { Consumers' } \\
\text { environment }\end{array}$ & 7.1. Decrease of customers' revenues & 7.2 Receiving subsidies for development \\
\hline 8 & Internal environment & 8.1. Increase of the rate of wastage & $\begin{array}{l}\text { 8.2. Increasing labor productivity, due to } \\
\text { an improvement of team spirit }\end{array}$ \\
\hline 9 & $\begin{array}{l}\text { Investments } \\
\text { environment }\end{array}$ & $\begin{array}{l}\text { 9.1. Decrease of the amount of } \\
\text { portfolio investments in the } \\
\text { pharmaceutical enterprises }\end{array}$ & $\begin{array}{l}\text { 9.2. Increase of investment } \\
\text { attractiveness of pharmaceutical } \\
\text { enterprises }\end{array}$ \\
\hline
\end{tabular}
uncertainty factors have been defined with the help of a questionnaire by the consultants of the enterprise (Table 1).

Table 1.

\section{Defining the Uncertainty Factors}

\section{Source: Elaborated by the author}

An example of calculation which uses the positive uncertainty factor no. 5.2 is presented below (tables 2,3, 4) 
Table 2.

The results of surveying the group of experts regarding the uncertainty factor 5.2 Reduction of cost of stock (Positive uncertainty)

\begin{tabular}{|l|l|l|l|l|l|}
\hline \multicolumn{2}{c}{$\begin{array}{c}\text { Expert } \\
\text { number }\end{array}$} & $\begin{array}{c}\text { The interval in which the probable } \\
\text { effect to the action of the factor no. } \\
1, \text { would be found out, thousands } \\
\text { RON }\end{array}$ & $\begin{array}{r}\text { The most probable interval in } \\
\text { which the effect caused by the } \\
\text { action of factor no. 1, would be } \\
\text { found out, thousands RON }\end{array}$ & $\begin{array}{c}\text { The degree of } \\
\text { uncertainty }\end{array}$ \\
\hline 1 & $\underline{\mathrm{m}}_{\mathrm{i}}$ & $\underline{\mathrm{n}}_{\mathrm{i}}$ & $\mathrm{p}_{\mathrm{i}}$ & $\mathrm{q}_{\mathrm{i}}$ & $\mathrm{h}_{\mathrm{i}}$ \\
\hline 2 & 255 & 300 & 275 & 280 & 0,9 \\
\hline 3 & 500 & 600 & 510 & 580 & 1 \\
\hline 4 & 1200 & 1500 & 1300 & 1400 & 0,8 \\
\hline 5 & 750 & 900 & 800 & 900 & 0,95 \\
\hline 6 & 620 & 650 & 630 & 640 & 0,9 \\
\hline 7 & 800 & 1000 & 850 & 950 & 0,85 \\
\hline 8 & 700 & 900 & 750 & 850 & 0,85 \\
\hline 9 & 300 & 500 & 350 & 400 & 0,9 \\
\hline 10 & 450 & 650 & 500 & 600 & 0,85 \\
\hline
\end{tabular}

Source: Elaborated by the author

Respectively, if a situation of negative uncertainty occurs (for example, damage caused by the stopping of the manufacturing process because of a delayed delivery of raw materials), then the results of the evaluation would be negative.

Table 3.

Representing the experts' in the form of fuzzy variables

\begin{tabular}{|c|c|c|c|c|c|}
\hline Expert number & \multicolumn{2}{|c|}{$\underline{\underline{m}}_{i} \quad \underline{n}_{i}$} & $\alpha_{i}$ & \multicolumn{2}{|c|}{$\beta_{i}$} \\
\hline 1 & 255 & 300 & 20 & 20 & 0,9 \\
\hline 2 & 500 & 600 & 10 & 20 & 1 \\
\hline 3 & 1200 & 1500 & 100 & 100 & 0,8 \\
\hline 4 & 750 & 900 & 50 & 0 & 0,95 \\
\hline 5 & 620 & 650 & 10 & 10 & 0,9 \\
\hline 6 & 800 & 1000 & 50 & 50 & 0,85 \\
\hline 7 & 700 & 900 & 50 & 50 & 0,85 \\
\hline 8 & 300 & 500 & 50 & 100 & 0,9 \\
\hline 9 & 450 & 650 & 50 & 50 & 0,85 \\
\hline 10 & 500 & 800 & 150 & 100 & 0,95 \\
\hline
\end{tabular}

Source: Elaborated by the author

The calculation for the factor No. 5.2. are made in table 4 below.

Table 4.

The Results of the calculation for the factor Nr. 5.2.

\begin{tabular}{|l|l|l|r|r|r|}
\hline \multicolumn{1}{|c}{ Indicators } & \multicolumn{1}{c}{$\mathrm{n}$} & $\mathbf{h}$ & $\alpha$ & $\beta$ \\
\hline Total evaluation & 6024 & 7843 & $\mathbf{0 , 8}$ & 489 & 457 \\
\hline Mean result & 602 & 784 & $\mathbf{0 , 8}$ & 49 & 46 \\
\hline The most probable interval of the result & & $\mathbf{6 5 1}$ & $\mathbf{7 3 9}$ \\
\hline The mean size of the result according to the factor No.5.2., thousands RON & & $\mathbf{6 9 5}$ \\
\hline
\end{tabular}

Source: Elaborated by the author

After the presentation of all the processed data from the experts' questionnaires, the total evaluation of uncertainty could be calculated for the chosen operational strategy:

$$
\mathrm{R}=4235,2-3752,4=482,8 \text { mii Ron }
$$

We point out that in general, uncertainty within which a decision of operational strategy is being made, could be recognized as positive. This evaluation enables the comparison of several variants of operational strategy from the point of view of expressing uncertainty. 


\section{CONCLUSIONS}

Summarizing the performed evaluation, we could assert that the uncertainty is a flexible characteristic, while a more stable basis of the operational activity is the potential of manufacture of the enterprise.

The research of the category of "uncertainty" in relation with the "risk" category has demonstrated the ambiguity of their interpretation and has revealed the necessity to distinguish between these categories. We have come to the conclusion that uncertainty is a measurable value through the expert method of evaluation and this one enables a favorable result, being mainly a characteristic of the external environment, an objective phenomenon and a condition for the existence of the business. While risk is a measurable value through empirical data, this implies an unfavorable result, being mainly a characteristic of the internal environment representing a subjective phenomenon dictated by somebody's wish.

Uncertainty in the modern business seems to be an important factor in the economic relations, dictating the need to use different prognosis methods and reduction of the risk degree. The following types of environment which could be considered sources of uncertainty could be distinguished: socio-economic; scientific and technical; political and juridical, environment of sales partners, environment of the seller, environment of competitors, environment of consumers and internal environment. As a result of interviewing the management team, through the survey carried out within industrial enterprises, it has been noted that the biggest impact upon the operational decisions of the companies is produced by the uncertainty generated within the consumption environment. The uncertainty from the internal, political, juridical, scientific and technical environment is analyzed to a lesser extent. The lowest degree of uncertainty is characteristic for the chemical industry and the highest for the industry of basic pharmaceuticals and pharmaceutical preparations.

\section{REFERENCES}

1. Armitage, D. H., \& Gardiner, S. J. (2001). Classical Potential Theory. Springer London. https://doi.org/10.1007/978-1-4471-0233-5

2. Doltu, T. (2006). Abordări în economia riscului şi incertitudini. Editura Economică.

3. Fields, J. (2012). Uncertainty: Turning fear and doubt into fuel for brilliance. Portfolio/Penguin.

4. Hammer, M., Somers, K., \& McKinsey and Company. (2016). Unlocking industrial resource productivity: Five core beliefs to increase profits through energy, material, and water efficiency. McKinsey Publishing.

5. Keynes, J. M., Krugman, P. R., Haita, C. M., \& Nicolae, C. (2009). Teoria generală a ocupării forţei de muncă, a dobânzii şi a banilor. Publica.

6. McConnell, P. (2016). Strategic risk management. Risk Books.

7. Mora-Camino, F., \& Nunes Cosenza, C. A. (2018). Fuzzy Dual Numbers: Theory and Applications (1st ed. 2018). Springer International Publishing: Imprint: Springer. https://doi.org/10.1007/978-3-319-65418-8

8. Zamfir, C. (2005). Incertitudinea: O perspectivă psihosociologică. Editura Economică.

\section{ARTICLE HISTORY}

Received 18 May 2020

Accepted 19 January2021 